\title{
JUN Gene
}

National Cancer Institute

\section{Source}

National Cancer Institute. JUN Gene. NCI Thesaurus. Code C19531.

This gene plays a critical role in transcriptional regulation and cellular growth. 